Divine development

Transnational Indian religious organizations in the United States and India

Agarwala, Rina

Published in:

International Migration Review

DOI:

10.1111/imre.12188

Publication date:

2015

Document version

Publisher's PDF, also known as Version of record

Citation for published version (APA):

Agarwala, R. (2015). Divine development: Transnational Indian religious organizations in the United States and India. International Migration Review, 1-41. https://doi.org/10.1111/imre.12188 


\title{
Divine Development: Transnational Indian Religious Organizations in the U.S. and India
}

\author{
Rina Agarwala \\ Johns Hopkins University
}

This article examines how Indian-Americans' religious organizations send not only financial remittances to India, but also social remittances that shape development ideologies. Comparing Indian-American Hindu and Muslim organizations, I find both groups draw from their socioeconomic experiences in India and use their position as elite immigrants in the U.S. to identify and empower their respective religious constituencies in India and overturn different social relations (not just religious practices). Hindu-Americans draw from their majority status in India to overturn India's lower position in the world system and support poverty-alleviation efforts within a neoliberal development framework. Indian Muslim-Americans draw from their poor status in India to overturn economic inequities within India by shifting India's development rhetoric from identity to class. Collective religious identities (expressed through organizations) not only affect the intensity of immigrants' development efforts, but also their content and ideology. These findings urge us to fold transnational religious organizations into contemporary discussions on migration and development.

International labor migrants have long been incorporated into national development strategies, reflecting what de Haas $(2010,227)$ called the "pendulum-like ideological swings in general paradigms of social and development theory." Specifically, states have used labor migrants to bolster economic growth when paradigms of globalization and liberalization have dominated development theory. During the 1950s-1970s, when the popular development strategy, known as import-substituting industrialization (ISI), encouraged developing country governments to attain self-sufficiency by nurturing local industries, preventing imports, and ending cross- 
country dependence, developing countries held an apathetic stance toward their emigrants abroad. ${ }^{1}$ In contrast, during the first era of mass globalization in the 1600 s, imperial empires relied heavily on labor migrants to bolster economic growth. Similarly, in the contemporary period of neoliberal globalization, labor migration has reemerged as an important channel (alongside trade and capital flows) through which countries try to strengthen their economies. For example, since the 1980s, India, China, Mexico, Morocco, and the Philippines have been relying on labor emigrants to relieve local unemployment and political dissent, build foreign exchange reserves, repay foreign debt, and ensure direct income transfers to low-income populations. In other words, countries of the Global South who are relying on the promises of globalization to foster development are trying to "export" labor migrants and "import" migrant incomes earned abroad.

These trends raise an important question to de Haas: If the ideological swings of social and development theory shape how migrants are incorporated into national development efforts, is the reverse also true? Do migrants shape the ideological frameworks of social and development theory? If yes, how? To begin addressing these questions, this paper examines how migrants' collective social identities shape development ideologies in sending countries. Specifically, I analyze how Indian-American Hindu and Muslim religious organizations are variously trying to shape development goals and ideologies in India.

Drawing from an inventory that I compiled of 624 Indian-American organizations, as well as 134 interviews with organization leaders and government officials that I conducted in the U.S. and India, I find that (in addition to sending financial remittances) Indian-American Hindu and Muslim organizations actively engage in remitting development ideologies and frameworks to India. I argue that these "social" remittances (Levitt 1999) of development ideologies differ across the two religious groups, because Indian immigrants use transnational religious organizations to shape Indian development ideologies in a way that assists their own religious constituency in India and the U.S. Each group constructs their respective religious constituency drawing from political and economic interpretations of experiences in India. Therefore, each group's development ideology addresses a different social relation. Hindu organizations address India's geopolitical inequality

\footnotetext{
${ }^{1}$ ISI was the favored development strategy in most of the developing world throughout the 1950 s and 1960s and was implemented with varying degrees of self-sufficiency. For more on ISI, see Gereffi (1994) and Hirschman (1968).
} 
with other countries, while Muslim organizations address class inequalities within India. The two groups differ in the type of poverty-alleviation projects they fund in India and the type of advocacy efforts they engage in with the Indian government. To further their development goals in India, both groups capitalize on their high socioeconomic status (SES) in the U.S.

These findings offer important insights into the sorely understudied topic of migrants' collective development efforts. As we know, organizations are more than and different from the mere sum of their individual members (Dimaggio and Powell 1983). This paper's findings on migrants' religious organizations and their interaction with states expand our understanding of the actors involved in the contemporary migration-development nexus. In addition, this paper offers insights into the equally understudied topic of the unique role of immigrants' religious identities on contemporary development ideologies. Modern organizations have long been said to reflect the myths of their institutional environments rather than the actual demands of their work activities, because doing so is more likely to ensure organizations' ability to attain legitimacy, resources, stability, and even survival (Meyer and Rowan 1977). Drawing from this, I use transnational religious organizations as an expression of immigrants' collective religious identities, which in turn are shaped by constructed (at times mythicized) understandings of religious communities as a social group embedded in particular socioeconomic relations in the homeland. Transnational religious organizations, therefore, reflect a social identity, not just a religious practice. This paper's findings on transnational religious organizations assert the spectrum of varying roles that immigrants' religious identities play in homeland development. Finally, this paper's findings expose the understudied channels of global power dynamics that undergird the contemporary migration-development nexus. The U.S.'s high status in the world system is said to have enabled immigrants to the U.S. to use religious identities to affect change in sending countries even though the U.S. is not the only migrant-receiving country and most holy centers are located outside the U.S. (Yang and Ebaugh 2001b). I find support for this claim among Indian-American immigrants.

In the following section, I outline the gaps in the contemporary literature on the nexus between migration, development, and religion. I then detail the methodology I use in this paper. The next three sections detail the empirical reality of Indian migration, religion, and transnational organizations in India and the U.S. I then develop my argument with data from my interviews on how Hindu and Muslim Indian-Americans draw on their position in the U.S. to shape development ideologies in India. In 
the concluding section, I suggest how these findings can improve our understanding of transnationalism and development.

\section{BACKGROUND: THE MIGRATION-DEVELOPMENT- RELIGION NEXUS}

\section{Migration and Development Literature}

An increasing consensus is emerging that transnational activities, while numerically small, are significant for shaping national development patterns in sending countries (Portes, Haller, and Guarnizo 2002; Guarnizo, Portes, and Haller 2003). Debates abound, however, on the consequences of migration on development and the actors involved in the process.

In recent years, many scholars have highlighted a positive correlation between migration and development ideologies that promote neoliberal globalization. These ideologies predict that incomes will grow when states absolve their regulatory role in the economy and release individuals' entrepreneurial capacities to participate in an unfettered, global marketplace. ${ }^{2}$ Among the many mechanisms that individual migrants can use to increase national incomes, the financial remittances they send home to their families have been the most studied. ${ }^{3}$ Since the mid-1990s, global remittances have exceeded overseas development aid (World Bank 2009). Strikingly, less educated migrants are more likely to remit (Durand et al. 1996). Remittances have thus been lauded for increasing the incomes of poor migrant-sending households, because they are direct and counter-cyclical (Massey, Durand, and Malone 2002; Rodrik 2005). At the macro-level, remittances are said to help sending countries bolster domestic savings, consumption and foreign exchange reserves, which helps finance imports, such as capital and oil, and ease balance of payment deficits (Russsell and Teitelbaum 1992). ${ }^{4}$

\footnotetext{
${ }^{2}$ For an excellent review of neoliberal theory, ideology, and practice, see Evans and Sewell (2013).

${ }^{3}$ Diaspora investments is another potentially significant mechanism through which national governments try to draw back migrant income, but its scale has been smaller, and it has been less studied.

${ }^{4}$ Remittances have also been critiqued for increasing regional inequalities and inflation, hindering agricultural production, and sustaining dependency. Because remittances are largely used for consumption and housing, and rarely for increased production or investment, many scholars argue they are most useful for short-term gains but fail to increase longterm economic growth (Massey et al. 2008).
} 
Recent studies, however, have argued that the migration-development nexus does not reflect the ideological predictions of neoliberal globalization; rather, it reflects the contradictions inherent in the implementation of these ideologies in the Global South. First, the growth and positive impact of migrants' financial remittances on sending country incomes are not due to a small state coupled with unregulated global market opportunities for individual migrants, but is rather the product of active governance by sending and receiving states. The Filipino government has "heroicized" migrants to retain their ideational connection to the Philippines, built a massive state bureaucracy to manage migrants' movements and remittances, and researched global immigration laws to facilitate bilateral agreements that secure niche opportunities for its citizens (Rodriguez 2010). The Indian government has launched the Overseas Citizenship of India (OCI) status, which has encouraged increased remittances through what Naujoks (2013) calls the "rights" and "identity" effects. ${ }^{5}$ The Moroccan and Mexican governments first engaged their emigrants to grapple with domestic political crises, and after decades of interactions between what Iskander (2010) calls a "creative," powerful state and active migrants, these countries experienced significant but unintended economic development. These studies have been instrumental in highlighting the state (not just individual migrants) as a key actor in the migration-development nexus, even in the contemporary era of neoliberal globalization.

Second, scholars interested in inequality and the structural constraints that prevent positive development have argued that migration has further entrenched hierarchies of wealth across countries (Valiani 2012), exacerbated status gaps between genders (Parrenas 2004; Walton-Roberts 2012), and increased local inequities by engulfing migrants into vicious cycles of indebtedness before departure and unemployment upon return (Khadria 2007). These studies have contrasted mainstream definitions of development that rely on income growth, to argue that economic provisions are embedded in social and geopolitical structures. "Development," therefore, must be defined broadly to include the range of actions that can shape the ideals, policies, practices, and power relations that ultimately determine people's material and symbolic life chances. ${ }^{6}$ Based on this definition, migration has exacerbated underdevelopment.

\footnotetext{
${ }^{5}$ For a detailed analysis of OCI's impact on remittances, diaspora investments, return migration, and philanthropy, see Naujoks (2013).

${ }^{6}$ These studies draw on a long legacy of development scholarship in sociology. For more, see Organski (1965), Huntington (1968), Evans, Rueschemeyer, and Skocpol (1985), Evans (1989), Arrighi (1990), and Wallerstein (1991).
} 
These studies on the active role of the state and increased inequality have deepened our understanding of how neoliberal globalization interacts with migration in the South - sometimes undermining contemporary development ideologies; sometimes furthering their darker, less articulated sides. Several gaps, however, remain to be filled. First, most studies to date, including those on the state, have focused on individual migrant activities, which are often undocumented and inconsistent and yield little insight into the growing genre of migrant's collective efforts. Some have examined the role that social networks play in perpetuating migration and remittances (Massey et al. 1987). Others have showcased the role that formal collective transnational activities play in financial and social development in sending countries (Portes, Escobar, and Radford 2007; Portes and Zhou 2012). This paper builds on this small and growing literature on transnational organizations as key actors (in addition to individual migrants and the state) in the contemporary migration-development nexus.

Second, although scholars have offered competing definitions of development (ranging from national income growth to relative deprivation and power relations), we know little about the processes through which national development ideologies, definitions, and strategies are shaped in the first place. The prevalence of income-based definitions of development has fueled a lop-sided interest in financial remittances and investments, leaving relatively little insight into "social remittances," such as the transmission of ideas, identities, practices, discourses, and politics (Levitt 1999). Greater insight into social remittances can help us expand our understanding of how emigrants may not only be contributing to income growth (or income inequality), but also shaping developmental goals and ideologies.

\section{Migration and Religion Literature}

This paper's investigation into how transnational religious organizations variously shape development goals and ideologies builds on existing research on immigrant identities and religion. Naujoks' (2013) study of Indian-American immigrants showed that civic, ethnic, and national identities play an important role in mediating the effects of diaspora policies on migrant's development efforts. If social identities affect the intensity of development efforts, it is reasonable to assume that social identities also affect the content and ideology of national development 
efforts in sending countries. In this paper, I use organizations as a reflection of expressed, collective social identities (Meyer and Rowan 1977). Clearly, no single organization represents the identity of an entire community. Immigrant organizations (alongside the social identities they reflect) vary across and within immigrant groups. Nevertheless, each organization is significant in that it reflects a deliberate effort to define and voice a social identity that represents at least one segment of the immigrant community.

Second, if civic, ethnic, and national identities play such an important role in migrants' development efforts, it is reasonable to assume that religious identities may also play a significant, and possibly unique, role. Scholars have long shown the power of immigrants' religious identities at the individual and community levels. In receiving countries, religious identities serve as sources of unification, empowerment, and social capital for immigrants facing invisibility, home sickness, or hostility in their host environments (Barth 1969; Kurien 2004b; Levitt 2004). Immigrants adjust and transform religious practices to incorporate their migration experiences, accommodate host country environments, and attract secondgeneration immigrants (Vertovec 2000; Yang and Ebaugh 2001b; Kurien 2004a). In the process, they build what Levitt and Jaworsky (2007) figuratively call "new religious architectures," and what Leonard (1997) materially calls prominent physical statements of "authenticity."

In recent years, scholars have shown how immigrants also use their religious identities to retain relations and affect social outcomes in sending countries. Peggy Levitt is often credited for first highlighting how closely knit immigrant communities in the U.S., such as the Miraflores migrants in Boston, transfer their religious (among other) identities, ideas, and practices to transform the social and political life of their sending villages (Levitt 1998, 1999, 2001; Ebaugh 2010). Similarly, Ebaugh and Chafetz (2002) show how religious congregations in Houston and New York (that are not tied to a single country) use transnational linkages, ranging from institutional networks to interpersonal ties, to draw on their religious practices in receiving countries to transform beliefs as deeply rooted as gender norms in sending regions and other receiving countries.

Although these works have highlighted how immigrants' religious identities (at the individual and community levels) shape ideologies across countries, they have not engaged the recent literature on how immigrant organizations shape sending country development. Additionally, 
many scholars have recently argued that immigrants' transnational religious identities have fundamentalist tendencies, which are shaped by political factors in sending and receiving countries (Bhatt 1997; Mathew and Prashad 2000; Rajagopal 2000; Prakash 2001; Bermanis, CanettiNisim, and Pedahzur 2004; Biswas 2004; Fair 2005; Falcone 2006; Kurien 2006; Levitt 2008; Taub 2010). Questions remain, however, on the impact that collective religious identities have on shaping (sometimes seemingly) non-fundamentalist development ideologies in sending countries. As well, we know little about how socioeconomic factors (in addition to political factors) in sending regions shape immigrants' religiously motivated development efforts at home. Finally, the recent literature on organized transnational development efforts has largely ignored the role of religious organizations.

Given the evidence of immigrants' increasing religiosity and organization (Yang and Ebaugh 2001b), the intersection of SES and religious identities in many countries, and the role that (non-religious) social identities play in shaping immigrants' development activities, the content and effects of immigrants' religious organizations on sending country development frameworks demand further exploration.

\section{METHODOLOGY}

\section{India, Hindus, and Muslims}

India and its emigrants in the U.S. provide an ideal starting point for this inquiry. First, the Indian government has recently launched several new initiatives that target its diaspora as a channel for development. Over 20 million people of Indian origin live outside India (GOI, Ministry of External Affairs 2000). In 2010, India became the world's largest remittance receiving country, earning US\$55 billion (World Bank 2011). Little is known, however, about how Indian immigrants' collective development efforts (at the economic and ideational levels) interact with the Indian government's development goals.

Second, Indian immigrants' religious groups actively engage in transnational practices. Indian-Americans' religious organizations rely on guidance from partner organizations in India (Levitt 2007) and serve as conduits for philanthropic donations from Indian-American immigrants for religious and non-religious causes in India (Najam 2006; Dusenbery and Tatla 2009; Agarwal 2010). Indian-American religious groups also 
help shape religious identities in India, sometimes fostering extremism and other times moderation (Kurien 2007; Levitt 2008; Kapur 2010b). Still, we know little about how these religious groups' activities shape development efforts and ideologies in India.

Third, Indian-American immigrants are religiously diverse and fairly homogenous in terms of class. As the birthplace of Buddhism, Hinduism, Jainism, and Sikhism, and the recipient of Christianity, Islam, Judaism, and Zoroastrianism, India is deeply religious and constitutionally committed to religious pluralism. Like other immigrants, Indians retain their various religious identities after emigrating. In many cases, they assert an even more conscious and determined transmission of their religious identity abroad than at home (Williams 1988, 1998). This retained or reasserted religious diversity among Indian-American immigrants enables me to conduct a comparative examination across Indian immigrants' religious groups while holding constant their SES and target nation.

Although Indian immigrants' religious organizations experience within-group variation in terms of religious practices and ideologies, I find across group variation in terms of development ideologies to be higher. This is not surprising. Despite Indian immigrants' class homogeneity across religion in the U.S., religious groups correlate with significant differences in SES in India (GOI 2006). Scholars have shown that immigrant religious groups are affected by their SES in sending regions. Yang and Ebaugh (2001a), for example, show that the minority versus majority status of Christians versus Buddhists in China affects their respective religious and ethnic identities in the U.S. To the extent that development efforts aim to reshape socioeconomic relations, I hypothesize that different Indian status groups, which may be constructed into what Meyer and Rowan (1977) call "mythicized institutional rules," will have different development goals, which in turn are expressed through their respective organizations.

To test this claim, I focus on Hindu and Muslim American immigrant organizations. Hindus comprise 80 percent of India's population and are well represented in the middle and upper strata of India's class structure. Muslims represent India's largest religious minority group, and they occupy the lowest rung of the Indian class structure (GOI 2006). Muslim Indian organizations also expose how a global religious group can impact a particular country. This contrasts with existing scholarship that 
tends to focus on religions born in a sending country, such as Sikhs or Hindus from India or Jews from Israel. ${ }^{7}$

\section{Organization Inventory and Interviews}

The results detailed in this article draw from a larger project entitled the Comparative Immigrant Organization Project (CIOP), which includes India, China, Vietnam, Dominican Republic, Mexico, and Colombia. CIOP examines a range of immigrants' transnational organizations, of which "religious" organizations represent one category. The project uses organizations as its unit of analysis, because they represent transnational efforts that are sustained and overt; they capture financial and social remittances; and they enable us to examine immigrant's development efforts based on immigrants' self-expressed motivation. Therefore, I am able to isolate sustained remittances motivated by a religious identity, rather than those tied to other identities such as alumni, profession, or political party.

To analyze Indians' transnational efforts, I first compiled an inventory of 624 Indian transnational organizations that operate nationally, virtually, and in the four metropolitan statistical areas (MSAs) where over 55 percent of the Indian-American population resides. ${ }^{8}$ All organizations in the inventory began before 2009, have had at least one project in India since 2005 , and are founded and led by a person of Indian origin. Therefore, the inventory reflects sustained transnational efforts motivated by immigrant logics, rather than those of multilateral organizations staffed by Indian-Americans. This inventory is the first of its kind for the U.S.-based

${ }^{7} \mathrm{My}$ examination of Hindu versus Muslim organizations is not imposing a distinction from the outside, but rather analyzing the empirical fact of a self-imposed distinction. Indian-American Hindus and Muslims are participating in religious organizations and are self-identifying and distinguishing themselves based on their respective religious identities. Each organization is evaluated as a reflection of one segment of a particular religious community. Therefore, my analysis is limited to organization members and does not make claims on the entire religious community or religious individuals who are not members of these organizations.

${ }^{8}$ The MSAs are: New York City (and Northern New Jersey, Long Island, and parts of Connecticut and Pennsylvania); Washington, DC-Baltimore (and parts of Virginia, West Virginia, and Maryland); Chicago (and Gary and Kenosha); and San Francisco (and Oakland and San Jose). Other significant MSAs of Indians not included in the study include Los Angeles, Philadelphia, and Houston. This information was drawn from the US Census and the Integrated Public Use Microdata Series (IPUMS-USA). 
TABLE 1

Distribution of Organization Type in Interview Sample Versus Inventory

\begin{tabular}{lcccc}
\hline \hline Organization Type & $\begin{array}{c}\text { Number in } \\
\text { Inventory }\end{array}$ & $\begin{array}{c}\text { Percent of } \\
\text { Inventory } \\
\text { Organizations }\end{array}$ & $\begin{array}{c}\text { Number } \\
\text { Interviewed }\end{array}$ & $\begin{array}{c}\text { Percent of } \\
\text { Interviewed } \\
\text { Organizations }\end{array}$ \\
\hline Religious/religious combination & 205 & 32.8 & 24 & 34.8 \\
Ethnic/caste/linguistic/identity & 166 & 26.6 & 12 & 17.4 \\
Development/health/education & 119 & 19.1 & 10 & 14.5 \\
Professional/Alumni & 51 & 8.2 & 13 & 18.8 \\
Arts/cultural & 50 & 8 & 5 & 7.2 \\
Human rights & 17 & 2.7 & 3 & 4.3 \\
Political & 16 & 2.6 & 2 & 2.9 \\
Total & 624 & 100 & 69 & 100 \\
\hline
\end{tabular}

"Religious combination" refers to organizations that combine religion with another aim, including development, arts, linguistic identity, human rights, political, and alumni.

Indian population. Data for the inventory were collected using on-line databases, Indian business directories, websites, Indian-American newspapers, and advertisements for the India Day Parade. Organizations were categorized based on their self-identified "type," because this is where I found significant variation. Multiple categories were allowed, but we found this option was primarily employed by religious organizations. As shown in Table 1, religious organizations are the most common form of Indian transnational organizations in the U.S., totaling over one-third (or 205) of the 624 organizations in the inventory.

To unfold the phenomenological approach of this paper, I then conducted semi-structured interviews with Indian scholars, Indian government officials, and leaders of transnational organizations in the U.S. and in India. Interviews with government officials, all of whom were involved in issues concerning overseas Indians, provided a useful lens into how the Indian state interprets its interactions with migrant organizations and how it translates these interactions into Indian development ideologies.

For the organization interviews, I first drew from my inventory to identify the principal organizations in each category. Principal organizations were defined as those that represent a significant portion of the community (be it an ethnic, professional, or religious group) and have a voice that is recognized by individuals, other organizations, and government officials in the U.S. and India. The final list of principal organizations varied in terms of membership size and budgets, enabling me to 
control for resource-based explanations. I then interviewed the leaders of the principal organizations in the U.S. and their partners in India. I focused on leaders for two reasons. First leaders provide official articulations of the discursive elements of organizations' collective efforts, thereby highlighting how different groups (not individuals) publically interpret and assign meaning to their own identities. Second, leaders are often the key conduits in transnational interactions between the U.S.- and India-based organizations and Indian government officials, and they thus provide the most insights into how their organizations translate their identities into development goals in India. By limiting my interviews to organizational leaders, I was able to control for intra-organizational politics and difference, which is not the focus of this article.

Interviewees were identified using a snowball technique based on interviews with scholars, activists, and other key informants knowledgeable about Indian diaspora affairs in the U.S. Because the network of Indian transnational organizations in the U.S. is relatively close and heavily influenced by the "major" organizations, this purposeful sampling technique offered more useful insights on general patterns than a random sampling approach (Neuman 2011). I found that organization leaders and government officials were eager to participate in the interviews as a way to increase the visibility of their organizations' goals, activities, and achievements; I had only one person decline the invitation to participate. $^{\text {? }}$

My interview sample of organizations roughly represented the inventory distribution of organizations by type, so 24 of the 69 interviews conducted in the U.S. were with the leaders of religious organizations, including those who self-identified under multiple categories. Interviews were held in person (at the organization office, in the leader's home, or in a restaurant) or over the phone and lasted 1-4 h. In India, I conducted 66 in-person interviews with leaders of the partner organizations interviewed in the U.S., government officials, and scholars. Eleven of these interviews were with the leaders of religious organizations that have worked with U.S.-based immigrant organization, and 15 were with Indian government officials who work with overseas migrants and could speak

\footnotetext{
${ }^{9}$ In the early phases, I encountered skepticism from leaders of Christian and Sikh organizations. This was overcome by employing kinship networks and introductions from withingroup informants.
} 
about the government's interactions with religious organizations. ${ }^{10}$ Interviews and site visits in India were conducted in the capital city of Delhi, and in the states of Gujarat and Andhra Pradesh. Both these states are prosperous, have embraced liberalization and globalization, and have pursued their diasporas as a development resource.

The interview transcripts were then coded by theme and analyzed to identify the varied patterns, actions, and interpretations of Indian-Hindu and Muslim organizations in the U.S. and India. This approach enables us to uncover the social processes and mechanisms that often remain hidden in survey data. As with most studies that draw from qualitative interviews, the findings in this study do not purport to be generalizable to all transnational religious organizations. Rather, they provide an important, extremely underexamined, meso-level contribution to our understanding of immigrants' collective transnational religious identities. Moreover, qualitative methods have long asserted the "process of discovery" is as much a part of the "process of justification" as is the "process of verification," and I argue that the findings detailed in this paper expand our understanding of the processes and actors involved in the migration-development nexus (Burawoy 1991, 8).

\section{DEVELOPMENT, MIGRATION, AND RELIGION IN INDIA}

India is no exception to the "pendulum-like ideological swings" in state attention to international migration. Under colonialism, the British Government sent Indian merchants and indentured servants to work on plantations in Africa, the Caribbean, and the Pacific Islands to foster the growth of the empire. After India gained independence in 1947, the pendulum swung away from the use of international migration to foster growth. At the time, the Indian government urged its emigrants to identify with their host countries, rather than India. This message fit well with India's nationalist ISI economic paradigm of the time and its political efforts to ensure national order and sovereignty. The newly independent Indian government was reeling from the bloody partition of independence, and Muslims who chose not to

\footnotetext{
${ }^{10}$ Government officials were from the Ministry of Overseas Indian Affairs, Ministry of External Affairs, Ministry of Home Affairs, and the Ministry of Minority Affairs in Delhi; the Department of Industries and Commerce, The Overseas Manpower Company of the Department of Employment and Training, and the Special Secretary of Non-Resident Indian Affairs in Andhra Pradesh, and the Non-Resident Indian Division of the Government of Gujarat, the Gujarat State Non-Resident Gujarati (NRG) Foundation, and the Gujarat Chamber of Commerce and Industry in Gujarat.
} 
emigrate to present-day Pakistan were being treated with suspicion by the majority Hindu population. To ensure national unity, the Indian government used the newly drawn physical boundaries of the Indian state (rather than religious affiliation) to define the nebulous boundaries of national identity. This message was welcomed by Muslims in India and by Indian emigrants (of all religious identities) in Africa and the Caribbean whose own loyalties were being questioned in their host countries.

In the mid-1970s, India began to reincorporate emigrants into its development agenda. To enable Indian citizens to take advantage of the growing labor demand from the rising oil incomes and labor shortages in the Middle East, the Indian government in 1976 suspended its 1922 Emigration Act that restricted unskilled migration abroad. As a result, thousands of unskilled and semi-skilled Indian construction workers, and later domestic workers, migrated to the Middle East, and the Indian government benefited from the foreign exchange earnings from emigrants' financial remittances. In my interviews, Indian government officials routinely credited Indian emigrants for India's ability to alleviate its capital account deficits (which were growing alongside rising oil prices) and avoid the 1973 global oil crisis. ${ }^{11}$

Despite this acknowledgement of the diaspora's impact on India's economy, however, it was not until the mid-1980s, when India began to alter its development ideology away from state-sponsored Fabian Socialism, that the pendulum swung completely back and the Indian government officially reduced the institutional barriers and negative stigma attached to the international exchange of goods and people. To reengage its diaspora, the government initiated the Emigration Act of 1983 to manage unskilled labor migration through registered recruitment firms, favorable bank accounts for overseas Indians, visas facilitating the diaspora's entry and property investment in India, and a bill to enable overseas Indians to vote. In 2003, the government inaugurated an annual conference, Pravasi Bharatiya Divas (PVD) or "Overseas Indian Day," to build relations with emigrants. In 2005, India became one of the few countries to create a national Ministry for Overseas Indian Affairs.

\footnotetext{
${ }^{11}$ Personal interviews with Oommen Chandy, Chief Minister of Kerala (March 22, 2012); Noyal Thomas, Director and CEO of Norka-Roots, NORKA Department, Government of Kerala (March 23, 2012); G. Gurucharan, CEO of Ministry of Overseas Indian Affairs, Indian Council of Oversees Employment and India Development Foundation of Overseas Indians (March 20, 2012).
} 
Within this context, scholars and policymakers in India continue to overlook religious transnationalism as a potential force in Indian development. Most policymakers assume faith-based organizations do not address economic or welfare issues. In addition, religious organizations touch on sensitive topics, which complicate the Indian government's official commitment to secularism. In my interviews with Indian government officials in charge of diaspora activities, I was repeatedly told that they do not interact with religious organizations, because their offices focus on "development". In other words, development and religious activities are conceived as mutually exclusive. ${ }^{12}$ In reality, however, my data indicate that religious organizations comprise the largest category of Indian-Americans' transnational organizations and thus represent a pervasive channel through which Indian immigrants maintain transnational relations with India and the Indian government (see Table 1).

\section{INDIAN IMMIGRANTS AND RELIGION IN THE U.S.}

In 2010, the Indian immigrant population in the U.S. was 1.7 million, making it the U.S.'s third-largest immigrant group after Mexicans and Filipinos and making the U.S. home to the second largest concentration of Indians after Myanmar (US Census Bureau 2009). Two traits characterize the Indian-American population across religious groups.

First, Indian immigrants to the U.S. are new. Aside from a small number of farmers who migrated to California from the Indian state of Punjab in the early 1900s, Indian migration to the U.S. did not begin until the 1965 U.S. immigration laws abolished the national origins quota system, enabling Americans to recruit professionals in industries deemed necessary for U.S. growth. Indians' English proficiency and training in science and engineering (both sponsored by the Indian government's commitment to industrialization during the 1950s) positioned them to take advantage of these shifts in U.S. immigration laws. From 1960 to 1990, the Indian-born population in the U.S. jumped from 12,296 to 450,406 (Gibson and Lennon 1999). Nearly half of the Indian-born population in

\footnotetext{
${ }^{12}$ Personal interviews with Noyal Thomas, Director and CEO of Norka-Roots, NORKA Department, Government of Kerala (March 23, 2012); G. Gurucharan, CEO of Ministry of Overseas Indian Affairs (MOIA), Indian Council of Oversees Employment and India Development Foundation of Overseas Indians (March 20, 2012); Dr. Alwin Didar Singh; Secretary MOIA (January 19, 2012).
} 
TABLE 2

Select Characteristics of Indians and Indian-Americans

\begin{tabular}{lc}
\hline \hline Indians in India & \\
Population, 2011 Indian Census (Provisional Estimate) & $1,210,193,422$ \\
Urban population (\%), 2010 $^{\mathrm{a}}$ & 30.1 \\
GDP per capita, 2010 (Current US\$) & $\mathrm{a}$ \\
Gini Index (UN) 2010 & 1,410 \\
Educational attainment (\%) & 0.368 \\
Secondary school, 2000 & \\
Middle school, 2000 & 31.4 \\
Primary school, 2000 & 46.3 \\
Mean years of schooling, 2010 & 59.3 \\
Unemployment rate (\%), 2010 & 4.4 \\
Indian immigrants (foreign born) in the U.S. & 2.7 \\
Number of foreign born, 2010 & \\
Rank among countries of birth for new LPRs, 2011 & $1,780,322$ \\
Occupation sectors (\%), 2010 & $3 r d$ largest \\
Management, business, science, and arts & 70.1 \\
Sales and office & 16.8 \\
Service & 5.7 \\
Production, transportation, and material moving & 5.9 \\
College graduates (or higher) (\%), 2010 & 74.3 \\
Median household income (\$), 2010 & 94,907 \\
Poverty Rate-All Families (\%), 2010 & 4.1 \\
\hline
\end{tabular}

${ }^{a}$ World Bank Data.

${ }^{\mathrm{b}}$ Government of India, Ministry of Human Resource Development (MHRD), Department of Education, Planning, Monitoring and Statistics Division Report of Selected Educational Statistics (2000-2001).

${ }^{c}$ US Census Bureau (2011).

the U.S. arrived after 2000 when employers recruited skilled Indians to staff the expanding information technology (IT) sector. Today, Indians consistently receive the bulk of $\mathrm{H}-1 \mathrm{~B}$ visas, which allow skilled overseas employees to temporarily work in the U.S.

Second, Indian immigration to the U.S. is elite (see Table 2). Nearly 75 percent of Indians in the U.S. are college graduates, and their median household income is over $\$ 90,000$. Indian-Americans' SES is higher than that of average Americans, Asian American immigrants, and Indians in India (GOI, Ministry of External Affairs 2000).

For our purposes, it is significant that these characteristics of IndianAmericans are consistent across religious groups, despite religious groups' varied SES in India. Unlike in India, Indian-American Muslims enjoy the same SES as the majority of Indian-Americans. According to the Pew Muslim American Survey (Pew Forum on Religious and Public Life 2007), 74 percent of Indian Muslims are U.S. citizens and 51 percent report an annual income of over $\$ 50,000$. More than 65 percent of Muslims came to the U.S. to pursue occupational or educational opportunities, and over one-third arrived during the dot-com boom. 
TABLE 3

Indian Population in U.S. and India by Religious Group

\begin{tabular}{lccc}
\hline \hline Immigrant Subgroup & $\begin{array}{c}\text { Share of } \\
\text { Indian-born } \\
\text { Population in U.S. } \\
\text { (2003 Cohort) }\end{array}$ & $\begin{array}{c}\text { Share of } \\
\text { Indian-born } \\
\text { Population } \\
\text { in U.S. }\end{array}$ & $\begin{array}{c}\text { b } \\
\text { Share of Indian } \\
\text { Population } \\
\text { in India }^{\mathrm{c}}\end{array}$ \\
\hline Hindu & 66.36 & 72 & 80.5 \\
Other (Sikh, Jain, Zoroastrian) & 12.95 & 7.2 & 2.26 \\
Christian & 11.89 & 4.8 & 2.33 \\
Muslim & 5.07 & 10 & 13.4 \\
Buddhist & 0.27 & 0 & 0.77 \\
No religion or no answer & 3.47 & 4.8 & 99.26 \\
Total & 100.01 & 98.9 & \\
\hline
\end{tabular}

${ }^{a}$ From (Jasso et al. 2006).

${ }^{\mathrm{b}}$ From (Kapur 2010a).

cFrom (GOI 2001).

Although SES is consistent across Indian-American Hindus and Muslims, their majority/minority status replicates that of India. Demographic data on Indian Hindus and Muslims in the U.S. are difficult to attain, because American laws prohibit data collection on religious affiliation. However, existing case studies provide some baseline (see Table 3). As in India, Hindus represent the majority of Indians in the U.S. ${ }^{13}$ Although estimates of Indian Muslims are even more difficult to attain, because they are usually subsumed under the category "South Asian," estimates indicate that IndianMuslims in the U.S., like in India, comprise a minority of the Indian population, ranging from 5 to 10 percent (Fenton 1988; Williams 1988).

\section{INDIAN TRANSNATIONAL ORGANIZATIONS IN THE U.S.}

Not surprisingly, Indian immigrants in the U.S. have formed transnational organizations in response to social and political events in India and the U.S. According to my interviews and inventory research, IndianAmerican organizations emerged in three phases. First, in the mid-1980s, the anti-Sikh riots in India galvanized overseas Sikhs to organize. As well, India's new pro-West, pro-business Prime Minister, Rajiv Gandhi, hosted several parties in the U.S. to personally encourage Indian-Americans to reconnect with India. Second, in the early 1990s, India faced an economic crisis and began to thaw its cold war relations with the U.S. These trends

\footnotetext{
${ }^{13}$ Some scholars claims that Hindus' share in the U.S. is similar to that in India. Kapur (2010a), Fenton (1988), and Kurien (2001), however, claim it is lower in the U.S. due to the higher share of Indian Christians and Sikhs in the U.S.
} 
coalesced in the Indian government encouraging Indian-Americans (and other foreigners) to invest in India. Simultaneously, the rise of Hindu nationalist movements and political parties in India inspired supporting and opposing organizations in the U.S. Finally, in the early 2000s, the IT boom drew an unprecedented number of educated Indians to the U.S. just as the backlash from the September 11 attacks made Indian immigrants uncomfortable. These events spurred new Indian immigrants in the U.S. to organize together.

Most transnational organizations in my inventory operate in a single city, while one-third are national or international organizations with local chapters. Approximately 10 percent serve as umbrella organizations. Indian transnational organizations tend to be small; 70 percent have less than 1,000 members, and 75 percent have an annual budget under $\$ 1,000,000 .{ }^{14}$ Over 70 percent of them have no paid staff and operate solely through volunteers. While most appeal only to ethnic Indians, 25 percent recruit non-Indian members, volunteers, staff, donors, and/or board members. In my interviews, I found that men are more active than women. Although women's participation is higher in religious and ethnic organizations where membership is family based, women are nearly absent from leadership positions across all organizations. First-generation Indians are more active than the second-generation, although some religious and development organizations provide exceptions (see below). Among firstgeneration immigrants, the younger cohort (largely IT professionals ages 25-40) is more active and has more trust in non-governmental organizations than the older cohort (traditional professionals ages 50 and above).

\section{Hindu and Muslim Transnational Organizations in the U.S.}

As shown in Table 4, Hindus, Sikhs, and Christians have the largest share of religious transnational organizations in the U.S., and Muslims have among the lowest. This is not surprising, given the relative size of the Indian-American Muslim population.

Although I find that Indian-American Hindu and Muslim organizations offer different development ideologies to India, my interviews indicate that they also share several characteristics, all of which reflect the institutionalized social construction of their religious identities. First, both

\footnotetext{
${ }^{14}$ For organizations that do not have members, I used the number of volunteers or donors.
} 
TABLE 4

Indian ReLigious Organizations in the U.S. ${ }^{a}$

\begin{tabular}{lcc}
\hline \hline Kind & $\begin{array}{c}\text { Number of Religious } \\
\text { Organizations }\end{array}$ & $\begin{array}{c}\text { Share of Religious } \\
\text { Organizations }\end{array}$ \\
\hline Buddhist & 3 & 1.5 \\
Christian & 61 & 29.9 \\
Hindu & 70 & 34.3 \\
Jain & 2 & 1.0 \\
Muslim & 5 & 2.5 \\
Sikh & 62 & 30.4 \\
Spiritual & 1 & 0.5 \\
Total & 204 & 100 \\
\hline
\end{tabular}

${ }^{a}$ From author's inventory. Includes religious combination organizations.

groups expressed their missions in terms of "the need to preserve their identities." In India, Hindus are a majority religion, but they claim to be under attack by the global religions of Islam and Christianity. In India and the U.S., Muslims (more tentatively and subtly) claim to be under attack by the global war on terror. Second, unlike other Indian transnational organizations, religious organizations (across faiths) rarely mentioned funding as a challenge. Leaders said diaspora members trusted them and were willing to generously donate. In other words, organizing under a "vulnerable" religious identity serves a strategic function.

Third, although both groups practiced their respective religions when they arrived in the U.S., neither group organized along socially constructed religious identities at first. During the 1950s and 1960s, the small group of Hindu Indians in the U.S. met informally to perform religious rituals in their homes - claiming that group worship is not emphasized in Hinduism and that the professional group of Hindu migrants in the U.S. had limited knowledge of Hindu texts and rituals. Muslims were, in fact, the first group of Indians to migrate to the U.S. in the early 1900s (alongside Sikhs). Rather than organizing along religious identities, however, they organized with Sikhs on their shared linguistic traditions and SES as farmers. When Muslim missionaries from Punjab came to the U.S. in the 1920s to preach the Ahmadiyya Islamic reform movement, Indian-American Muslims did not participate. Instead, they created organizations to fight for broad "South Asian" representation in the U.S. and for Indian independence from the British. Similarly, in the mid-20th century, Indian-Muslim migrants from Hyderabad, who were often connected to the royal family, tried to maintain their prestigious status in their home country while adapting to their host country through organizations such as the Hyderabad 
Foundation that appealed to their social status at home, rather than their religion (Moore 1995; Leonard 2002).

Both groups began to organize along their respective religious identities soon after the 1965 surge in Indian immigration to the U.S. This shift reflects the ability to construct and mobilize a shared social identity only once a critical mass is present. But it also parallels the mid-1960s shift taking place in India as the secular independence movement began to fade against a reassertion of religious identities.

Among Hindus, the first U.S.-based organization was the Vishwa Hindu Parishad of America (VHPA), founded in 1970 by a small group of Indians who sought to unite the diverse group of local Hindus. Like many Hindu-American organizations that followed, VHPA is tied to a parent body in India. VHPA's parent body is called VHP, which was founded in 1964. ${ }^{15}$ VHPA taught Hindu "culture" to Indian immigrants by publishing pamphlets on how to conduct rituals, such as marriage, and recommended priests for communities looking to establish Hindu temples. Although VHPA's nationalist, conservative stance does not represent all Indian-American Hindus (or their organizations), it does represent the most organized, volunteer-run, national Hindu organization in the U.S. In 1977, the first Hindu temple in the U.S. was inaugurated in New York. Hindu temples in the U.S. not only enable individual religious practice, but also serve as spaces to build communities, host education seminars, and foster public religiosity.

After 1965, Indian-Muslims' professional status and English proficiency catapulted them into leadership positions in the broader MuslimAmerican community (Leonard 2003). Indian-Muslims were appreciated for being familiar with secular democracy and understanding how to live as a religious minority. They joined other Muslim-Americans in organizing under a global Muslim identity, leading pluralist mosques that superseded national allegiances to fulfill the umma or "universal brotherhood" tenant of Islam. According to my interviews, some Indian-Muslims launched new mosques in the 1980s that simultaneously recognized their Islamic and Indian identities. As with Hindu temples, Indian Muslim

\footnotetext{
${ }^{15}$ According to Abhaya Asthana, General Secretary of VHPA, the founding members of VHPA were not previously affiliated with VHP in India, but several were part of the Rashtriya Swayamsevak Sangh (RSS). The RSS is a prominent, all-male, Hindu nationalist volunteer organization that was founded in India in 1925. In India, VHP and RSS (alongside the right-wing political party, Bharatiya Janata Party [BJP]) are members of a controversial umbrella organization, called the Sangh Parivar, which advocates for Hindu nationalism.
} 
mosques in the U.S. not only transmitted religion, but also served to build a collective identity by providing space for family rituals, the preservation of Islamic culture, and the recognition of Indian linguistic needs for immigrants who were not fluent in English or Arabic. Unlike Hindu temples, Indian Muslim mosques served the added function of addressing the divisions that were growing among South Asian Muslim immigrants as geopolitical tensions between Indian and Pakistan continued.

With the assertion of different religious identities among IndianAmericans also came divergent agendas toward Indian development. As I illustrate below, these agendas vary more across religious groups than within religious groups. Given the range of Indian-American religious organizations (in terms of levels of fundamentalism), this finding is significant. Hindu and Muslim Indian-American organizations channel their transnational religious activities toward overturning social power relations that involve India. However, the different sociopolitical and economic experiences of Hindus versus Muslims in India have urged their respective transnational organizations to address different social structures and thus set different development agendas for India. Each development agenda has different visions for India's relationship to other countries and class inequities within India.

\section{BOOSTING INDIA IN THE WORLD SYSTEM}

Sociologists of development have long illustrated how improvements in human welfare, that is, "development," demand alterations in global power structures, because such structures determine the relationships that ultimately determine people's material and symbolic life chances (Frank 1966; Arrighi 1990; Wallerstein 1991). I find that more than any other Indian transnational organization (including other religious organizations, as well as development, professional, ethnic, and alumni organizations), Hindu-American organizations are working toward this development goal by trying to boost India's geopolitical standing and independence in the world system. Unlike development sociologists, however, Hindu organizations try to do so within an ideological framework of neoliberal globalization. Although these aims were expressed most acutely and prominently by organizations that support Hindu nationalist politics, they were also condoned by non-nationalist Hindu organizations.

To motivate this development goal, Hindu organizations highlight the sociopolitical power that the majority Hindu population holds in 
India alongside the vulnerability Hindus face from larger global religions. To further their goal, Hindu organizations frame India as a homeland for Hindu citizens across the world, including those living in wealthy, powerful core countries like the U.S.; they also foster U.S.-India bilateral alliances. This approach stands in sharp contrast to that of Indian Muslim organizations in the U.S., who highlight Muslims' vulnerable sociopolitical position in India to frame India as a secular nation under threat that needs assistance from the global community, especially from those who reside in powerful core countries like the U.S. that share their ideals of secularism. In both cases, the organizations assert a particular development goal and ideology based on a constructed social identity of their own religious constituency in India. Institutionalizing these constructed identities helps legitimize their respective organizations. Both sets of organizations also use migrants' high SES in the U.S. to empower their respective development efforts in India.

A key component of Hindu organizations' attention to boosting India's geopolitical position in the world is their articulation and reiteration of Hindus' majority status in India. Developing India's reputation in the world, therefore, translates into empowering Hindus. Ultimately, these efforts also enable Hindu-American organizations to legitimate their own status, authority, and space in the U.S., while simultaneously shaping India's development goals.

To further these efforts, Hindu organizations invest heavily in attracting multigenerational support from Indians-Americans. Indeed, their success in attracting second-generation youth has been well recognized. My interviews confirmed that they have been more successful than other Indian-American transnational organizations (including other religious organizations) in doing so. Nearly all my interviewees said they joined Hindu organizations to ensure their children retained their Hindu heritage, and they proudly asserted the involvement of second-generation youth in their organizations' activities. In addition to ensuring their children exhibit familiar ritual and spiritual affiliations, scholars have shown that HinduAmerican organizations help Indian immigrants channel their children's adolescent sexuality into "safe" and familiar pathways by speaking about the use of contraception, divorce, adultery, and homosexuality (Jaffrelot and Therwath 2007). By highlighting the "greatness" of Hinduism, Hindu organizations also help second-generation Indians cope with racial marginalization in the U.S. (Rajagopal 1997; Mathew and Prashad 2000; Kurien 2005). Less recognized, however, is how Hindu organizations' attention to 
the second-generation reflects migrants' efforts to reshape India's development goals to focus on boosting India's geopolitical position in the world system.

My interviews indicate that to attract the second generation, Hindu transnational organizations use a two-pronged approach that ultimately draws diaspora attention back to India. First, Hindu-American organizations offer Hinduism as an identity that simultaneously spans national boundaries, but is rooted in India. Several leaders claimed the need to create a Hindu identity, because national identities would soon no longer exist. As Abhaya Asthana, General Secretary of VHPA explained:

\footnotetext{
We are all good closet Hindus...Being a good Hindu as an individual is one thing. But do I feel something in me when something happens to another Hindu in Malaysia or Pakistan or Fiji where I need to protect my brother and sister? When that feeling comes, then we are connected in the social environment. That is Hindutva. When we feel we are one community, across states. When we share a culture, a civilization, a heritage. ${ }^{16}$
}

This perspective has appealed to Hindu immigrants in the U.S. Today, the VHPA has 20 chapters and 4,000 members. The organization works at the national and local levels in India and the U.S. Their activities in the U.S. include running soup kitchens and blanket distribution in inner cities. Their activities in India include a village education program called Ekta Vidyala as well as a child adoption program that operates through local NGOs. Swami Vigyananand, Joint General Secretary and Head of International Coordination of VHP in India, relayed a similar sentiment, "VHP doesn't focus on Indian identity. Instead we push for a civilizational identity. You can be American. We just say 'be Hindu'."17 This approach enables Hindu-Americans to retain their loyalties to the U.S., rather than having to choose between the U.S. or India. As one VHP leader stated, "In fact, we want Indians in the U.S. to focus on the U.S." At the same time, Hindu organizations emphasize India as the Hindu "homeland." This is significant for encouraging the diaspora's connection to and financial support for organizations in India.

Second, Hindu organizations vest heavily in educating second-generation Indian-Americans, which creates a shared identity with Hindus in

\footnotetext{
${ }^{16}$ Interview April 7, 2011. This quote reflects VHPA's definition of the controversial term "Hindutva." Critics argue that the term captures an ideology of Hindu nationalism that preaches violence against religious minorities in India (especially Muslims and Christians).

${ }^{17}$ Interview May 25, 2011.
} 
India. Organizations hold weekly bal vihars (religious classes) and Hindu Heritage summer camps to teach yoga, prayers, Hindu history, and texts. In addition to serving a theological function, these programs aim to increase Hindu-Americans' confidence to express their religious differences to non-Hindu-Americans. "We try to give young people clear tips on how they can practice their own religion in their dorm or on a class trip, but also how to explain it to their peers and answer derogatory questions," explained a Director of Media Relations at BAPS Swaminarayan Sanstha, the New York branch of one of the world's largest Hindu organizations. ${ }^{18}$ In doing so, these programs also increase Indian-Americans' ability to identify with Hindus in India. The international chapters of BAPS are closely overseen by the head organization based in the Indian state of Gujarat. The first BAPS mandir was built in New York in 1974, and the national office was established in 1988. The New York branch has a few full-time employees and does not hold regular elections for leadership; the current head has been in place since 1996. BAPS is a large international organization with 1.5 million members internationally and over 1,000 members in the U.S. In both the U.S. and India, BAPS operates at a national level. They conduct similar activities in both countries, including fundraising, providing education and training services, and religious activities. In India, they support economic development projects as well as humanitarian relief after natural disasters.

By attracting multigenerational Indian-Americans' attention back to India (through a geographically flexible national identity that includes India as a Hindu homeland and a shared religious identity with Hindu Indians), Hindu organizations capitalize on Indian migrants' high SES in the U.S. and their core country residence to boost the perceived power of Hindu society, which in turn is represented by India. As Vigyananand explained, "Wherever the [Hindu] Diaspora is living, they should live with dignity and respect. They need to have a good position in societyin politics, economic, business, education. That will be good for Hindu society in their country and that is what VHP expects from the Diaspora." 19

An interesting component of Hindu organizations' efforts to boost India's global position involves their advocacy efforts with the Indian government to further support neoliberal development ideologies. These ide-

\footnotetext{
${ }^{18}$ Interview May 29, 2011; Interviewee requested to remain anonymous.

${ }^{19}$ Interview May 25, 2011.
} 
ologies are credited for empowering Hindu-American migrants, as well as Hindus in India. As Vigyananand noted, "The [Indian] economy since liberalization has certainly generated confidence, which helps the global Hindu society's dignity." 20 In addition, these ideologies are used to generate India as a U.S. ally. Within Hindu organizations, several interviewees (in India and the U.S.) expressed a commitment to U.S.-friendly policies such as fighting socialism, supporting Israel, promoting free markets, and cementing a friendship with the U.S.

Motivating this development goal is a framing of Hindus under a civilizational onslaught by global religions (such as Christianity and Islam) in the U.S. and in India. Hindu organizations institutionalize this defensive, mythicized frame by promising to defend Hinduism, a promise that is powerful in attracting multigenerational support among Hindu-American immigrants. A strong U.S.-India alliance is seen as crucial to this effort. Anil Vartak, Secretary of the Delhi office of Rashtriya Swayamsevak Sangh (RSS), said, "We are against Socialism. We support Democracy as deeply Indian. Our panchayats [village governments] had democracy well before the U.K. Parliamentary system was brought to India. We are not against liberalization and globalization. But we oppose the exploitation that is being impressed on developing countries by the West in this context." ${ }^{21}$ Hindu organizations' fight for Indian power in the world system, therefore, does not critique the economic inequities and power relations ingrained in liberalized, capitalist democratic systems; in fact, they fully support the ideal of a free, global market. Rather, boosting India's geopolitical position to that of the U.S. core position is framed as a pathway to empowering Hindus.

Although some Hindu organizations claimed not to have any official political stance, many Hindu organizations in the U.S. work closely with the BJP, India's right-wing political party that is a member of the Sangh Pariwar, a controversial umbrella organization that champions Hindu nationalism. The religious leaders of BAPS in the U.S., for example, frequently meet with Narendra Modi, the BJP Chief Minister of Gujarat from 2004 to 2014 and current Prime Minister of India. The BJP was one of the first Indian political parties to set up an official U.S. office for the diaspora, known as "Overseas Friends of BJP." This organization was established in 1992 to "correct misconceptions" that had formed about

\footnotetext{
${ }^{20}$ Interview March 25, 2011.

${ }^{21}$ Interview, March 22, 2011.
} 
the BJP and its role in the controversial movement to build a temple on the grounds of the Babri Mosque in the northern Indian city of Ayodhya. They have 500 paying members and 300 "complimentary" members across several chapters in the U.S. They engage in political advocacy in the U.S., including presenting research papers on foreign policy matters to American congressmen and think tanks. They also present papers to the BJP in India to advise them on U.S.-India relations. According to the president of the Overseas Friends of BJP, Dr. A.V. Prasad, they have been very committed to maintaining a friendly relationship between India and the U.S. As Vijay Jolly, the India-based Vice President and Spokesman for BJP and BJP Joint Convenor of External Affairs in India, explained:

\footnotetext{
The relationship [between India and the US] is not just in business or on a government level. The one-to-one people connection is huge, especially at a religious level...BJP in the US finds IT folks, doctors, lawyers and individuals that BJP connects to by attracting them to our values. And we don't feel shy in telling that we are proud to be Hindu. We are preaching a universal brotherhood. No other religion is inferior to us. We consider Hinduism as the ancient religion that all others came from. The global civilization started with Hindus."22
}

By increasing Hindu-Americans' confidence in expressing their Hinduism, connecting their Hinduism to the homeland of India, and promoting India as an economic (i.e., free-market capitalist) and political (i.e., democratic) ally of the U.S., Hindu-American organizations seek to support neoliberal development frames in India and boost India's developmental status to that of a powerful global Hindu player. In doing so, they aim to increase Hindu immigrants' status and confidence as powerful minorities in the U.S. and as important actors in India. These efforts are motivated by Hindu organizations' reiteration of Hindus as the majority of India (and therefore of "Hindu" and "Indian" identities as interchangeable), as well as Hindus under attack from other religions. As a result of this strategy, Hindu-American organizations are supporting an Indian development framework that focuses on inequalities between India and the U.S. and deflects attention away from class inequalities within India.

Hindu-Americans' vision for Indian development goals stands in sharp contrast to that of Indian Muslim organizations in the U.S., who do not attempt to assert India's independent power in the world

\footnotetext{
${ }^{22}$ Interview May 11, 2011.
} 
community, but rather assert India as a nation under threat that needs assistance from the world community. Their development goals for India, therefore, focus on reversing inequities within India, rather than inequities between India and other countries. As with Hindu organizations, IndianMuslim organizations draw on constructed understandings of Muslims' experiences in India, alongside assertions of Indian Muslim immigrants' power in the U.S., to legitimize their organizations and further their development goals.

During the 1980s, as Hindu nationalism grew in India, Indian-Muslims in the U.S. launched new organizations to articulate the experiences of Indian Muslims in sociopolitical terms. The Islamic Society of North America (which superseded national boundaries) formed the Indian Muslim Relief Committee (IMRC) to expose the violence taking place against Muslims in India. IMRC built off an earlier model pioneered by the Consultative Committee of Indian Muslims (CCIM), which began in 1967 to promote unity between Indian immigrants of different faiths and to emphasize India's secular traditions. Both organizations aimed to inform Americans of communal violence in India with the hope of breeding global action to stop the violence. In 1989, IMRC held a conference at Stanford University entitled, "North Americans in Support of Indian Muslims," where activists and social scientists articulated Muslims in India as "vulnerable" and put forth a strategy to empower them. This meeting catalyzed a series of Indian-Muslim organizations to form in the U.S. Unlike their Hindu-American counterparts, these newer Indian-Muslim organizations tended to be independent of an India-based parent organization, although they often worked with Indian-Muslim groups in India.

Similar to the defensive frame launched by Hindu organizations, the overarching frame of the 1989 IMRC meeting was that Muslims in India are victims; unlike for Hindus, Muslim victimization occurs within India, where Muslims lack sociopolitical and economic power. Like other religious transnational organizations, Indian Muslim organizations offered to protect their unique identity. In doing so, they also institutionalized the identity, thereby lending legitimacy to their organizations. As Rasheed Ahmed, Founding Member and former President of the Indian-American Muslim Coalition (IAMC) in the U.S., explained, "Indian-Muslims did not have a distinct identity. When we were in professional groups, we were counted as 'Indians', when we were in mosques we were counted as 'Muslims'. This was fine for a while. But after the massacre in Gujarat, we realized we had to come together to do something. The event really 
disturbed us." 23 While many Indian Muslims were already involved in charity work, after the Gujarat riots in 2002, a small group formed IAMC to articulate a unique identity for Indian Muslims and to mobilize them in the U.S. Today, IAMC is a medium-sized, national organization with 11 chapters and one full-time employee. In the U.S., IAMC builds networks among Indian-American Muslims, provides support for immigration documentation, and supports research on Indian Muslims. In India, they participate in political advocacy by writing letters and meeting with Indian government officials. They are not affiliated with political parties in India, but rather target the Indian administration in their advocacy work.

Like Hindu organizations, Indian-Muslim organizations drew on their status as residents in the U.S. to further their development goals for India. At the 1989 meeting, some suggested launching an American lobby of Indian-Muslims that could raise awareness in the U.S. about the ill-treatment of Muslims in India and then pressure the Indian government to protect Muslims (Khalidi 1989). Throughout the proceedings, there was a loyal appreciation expressed for the freedom of religion and human rights purported in the U.S. At the same time, there was a cogent understanding that Hindu-American Organizations were promoting Indian independence in the world system and a fear that appealing to U.S. pressure could promote a Hindu backlash against Indian-Muslims for partnering with a "foreign superpower" to undermine India's national sovereignty (Wright 1989).

To avoid such a backlash, Indian-Muslims in the U.S. were encouraged to participate in India's political process as nationalist Indians and to even work with Hindu nationalist organizations. Doing so would blunt suspicions of their disloyalty in India and the U.S. Following this strategy, Indian-Muslim organizations, unlike Hindu organizations, do not assert their identity against another group; rather, they frame their needs as part of India's national interest. Similarly, India's national interest is articulated relative to the ideals of secularism originally voiced at independence; it is not articulated in terms of its geopolitical power relative to other countries in the world system.

\footnotetext{
${ }^{23}$ Interview April 27, 2011. The interviewee is referring to the 2002 anti-Muslim riots that took place in Gujarat. It is estimated that thousands of Muslims and hundreds of Hindus were killed and injured during these riots. State officials (including the police and thenChief Minister of Gujarat, Narendra Modi) have been accused of planning and condoning the riots.
} 
In their attempts to promote secular democracy and empower poor Indian-Muslims, Muslim organizations have been politically active in India. As Dr. Mukhi of AFMI in the U.S. noted, "We are a non-political organization...But we do invite politicians and speak to them. You need to be political to get things done in India." ${ }^{24}$ Nearly all the interviewees in Muslim organizations spoke of their advocacy work in India, such as fighting communal violence and pressuring the India government to address the economic underdevelopment of Muslims through education and job reservations. Some Indian-Muslim organizations also work with organizations in India to reform Muslim practices on divorce and marriage.

To underline their loyalty to India (over Pakistan), Muslim organizations offer to use their connections to the U.S. to garner support for India. For example, they lobbied U.S. government officials to intervene during the Pakistan-supported Kargil conflict in 1999, advocated for the nuclear deal in 2008, and demanded the U.S. to condemn Pakistan for the Mumbai terrorist attacks in 2008. Doing so enables them to increase further their development visions and legitimize their organizations. As Kaleem Kawaja of the Association of Indian Muslims (AIM) said:

\footnotetext{
We are active in putting pressure on Pakistan for terrorism. From the beginning it has been our objective to not cut ourselves off from other Indians. But we are not only doing it for geo-political reasons. We do it because it is consistent with our demands for India. We fight against all acts of violence. Otherwise we have no legitimacy to speak for Muslims. Our credibility lies in just causes. ${ }^{25}$
}

\section{OVERTURNING INDIA'S CLASS STRUCTURES}

For decades, sociologists have shown how class structures determine people's material welfare; "development" or the improvement of people's material well-being, therefore, relies on altering class structures in a way that empowers the most exploited classes (Brenner 1985; Rueschemeyer, Stephens, and Stephens 1992; Moore [1966] 1993). I find that more than any other Indian transnational organization (including other religious organizations, as well as development, professional, ethnic, and alumni organizations), Indian-Muslim American organizations are working toward this goal by framing Muslims in India as an exploited lower class and by seeking to overturn this class structure by empowering Indian Muslims

\footnotetext{
${ }^{24}$ Interview April 19, 2011.

${ }^{25}$ Interview, April 26, 2011.
} 
passed their socioeconomic deprivations, primarily through education. This approach stands in sharp contrast to that of Hindu-American organizations, which promote a top-down charity approach to poverty alleviation that retains existing class structures. Both groups expressed the motivation for their respective strategies in terms of Hindu versus Muslims' socioeconomic identities and experiences in India.

Indian-Muslim organizations in the U.S. have launched several projects in India that explicitly focus on empowering those at the bottom of the class structure; it is no coincidence that this is where many fellow Muslims reside. To avoid a backlash from the Hindu majority, Muslim organizations avoid framing their efforts as revolutionary and instead emphasize their utilitarian function for India as a whole. As Dr. Shakir Mukhi, Former President of the American Federation of Muslim Indians (AFMI) in the U.S., explained, "When we are trying to raise funds, we explain that a bad neighbor brings down the value of your house. Similarly, if one section of the community is educated, and another is not, it won't do anything for the country. People will fight and bring the country down." ${ }^{26}$ AFMI is one of the largest Indian-Muslim development organizations in the U.S. and currently has 25,000 members and supporters. Their activities in the U.S. include fundraising and organizing trainings for Indian Muslim school teachers in the U.S. In India, they offer scholarships and other awards to students and have helped establish schools, clinics, and hospitals.

Similarly, as Kaleem Kawaja of AIM in the U.S., noted, "We want to fight for human rights in India, but at the same time we do not want to be used by Pakistan [as an anti-Indian force]. So we cooperate with the Indian Government to represent Indian-Muslims. We want to make Indian-Muslims visible in India. Not as individuals. But under the banner of an association. And we want to show that Indian-Muslims are not anti-India, but they are against sectarian violence." ${ }^{27}$ Once again, IndianMuslims as a social group are constructed in a way that not only informs Muslim organizations' development goals, but also legitimizes those very organizations. AIM is among the oldest Indian-Muslim development organizations and today it has 300 members in 12 states. Like AFMI, AIM too offers scholarships to Muslim students and has helped build or fund schools in India. AIM also engages in advocacy work by targeting Indian

\footnotetext{
${ }^{26}$ Interview April 19, 2011.

${ }^{27}$ Interview April 26, 2011.
} 
government officials and presenting them with memoranda about human rights violations and economic hardships faced by Indian Muslims. Shaheen Khateeb, Founding Member and former General Secretary of IAMC, reiterated the point succinctly, "We want India to be a more perfect country. What we want is India to flourish. We are proud to be Indian. And we don't want any part of the society to be left behind." 28

This position of asserting their Muslim identity within an Indian nationalist framework has given Indian-Muslim organizations an extraordinary opportunity to shape development in India in a way that assists Indian Muslims. They strive to retain the principles of secularism, pluralism, and democracy that are the bedrock of the Indian constitution, but that have been challenged by the Hindu right in recent years. As Kurien (2001) detailed in her case study, AFMI defines Indian history and the ideal Indian state as a project of multiculturalism. Over a decade later, I find Indian Muslim organizations still view these principles as the surest way to empower Muslims in non-Muslim settings. These approaches also connect Indian-Muslims with the educated Indian elite of the independence movement. For this reason, Indian-Muslim organizations in the U.S. are entirely built around combination identities (such as development and human rights), rather than purely religious identities. IndianMuslims who wish to focus solely on the religious tenants of Islam tend to work more closely with a global mosque.

To overturn Indian class structures, and thus empower Indian Muslims, Indian-Muslim organizations target education in India. Said Dr. Mukhi of AFMI, "Our objective is simple: educate, educate, educate." Indian-Muslim organizations frame their focus on education as a way to ensure the long-term economic empowerment of all minorities at the national level. To justify their attention to Muslims (relative to other minorities), Indian-American Muslim organizations highlight Muslims' underprivileged status in India. In 2001, the Indian Census released the cross tabulations of various demographic data by religious affiliation for the first time, and in 2006, it published the Sachar Committee Report, which detailed the marginalized position of Indian-Muslims in education, employment, and political representation (GOI 2006). Indian-Muslim organizations in the U.S. supported efforts to collect the data and helped disseminate the findings to Indian government officials and to U.S.-based companies trying to work in India.

${ }^{28}$ Interview April 27, 2011. 
Through these efforts, Indian-Muslim organizations are trying to reframe development discussions in India to focus less on identity and religion (where Hindus are the clear majority) and more on class (where the minority of Muslims are better highlighted). Of all transnational Indian organizations, Indian-Muslim organizations are unique in their focus on the intersection of religion and class.

The development ideologies undergirding Indian-American Muslim organizations' efforts contrast with those underlying Hindu-American organizations' poverty-alleviation efforts in India. Hindu-American organizations began to address poverty alleviation in India fairly recently (Anand 2004b). Many of these efforts began during the 1990s when Hindu organizations were criticized for supporting Hindu nationalist movements and illegally raising money to support violence against Muslims in India. While the evidence for these claims is under deep dispute, the claims had an indisputably negative impact on the public image of Hindu organizations. To counter the attacks, many Hindu organizations organized under what Raymond Williams $(1988,40)$ calls “ecumenical Hinduism." These organizations include Hindus of different regions, languages, and sects. Examples include the Hindu American Foundation (HAF) and VHPA. Because ecumenical Hinduism tries to unite groups that lead separate existences in India, its leaders often call on diaspora members to develop this organizational form in India. These groups are large and diverse and are well equipped to counter attacks on their politics.

The other track that Hindu organizations used to deflect attention away from the religious controversies that several interviewees mentioned was to reclassify their organizations under multiple identities in addition to Hinduism. Some registered as legally separate "development" organizations that remained ideologically related to their "sister" Hindu organizations. Some called themselves "Indian," rather than "Hindu" as an assertion that India is predominantly Hindu and as a political statement against India's pluralist model of state secularism. Others, such as the Gujarati Samaj or Tamil Sangam, organized around religious and sub-ethnic identities that support regional development projects. This shift to multiple self-identities is reflected in the high share of "religious combination" organizations among Indian-Americans.

Unlike their efforts to boost India's position in the world system, which is conducted at the national level and aims to unite the majority Hindu population under one umbrella, Hindu-American organizations' poverty-alleviation efforts are concentrated locally. They focus on service 
delivery on topics that are non-controversial among the elite U.S. diaspora - namely education, orphans, disaster relief, and food drives. Some also offer community services in the U.S. Hindu organizations often frame their efforts (in India and the U.S.) within the Hindu concept of sewa, or selfless service, and thus focus on the individual level rather than broad structural changes. A few organizations frame their development efforts as empowerment, and interviewees pointed to their programs in rural health, micro-businesses for women, and tree planting. But most of these efforts served as a complement to their primary efforts to organize and defend Hindus, rather than overturn class structures. Several organizations reiterated their development efforts target all Indian communities and are not limited to Hindus. While this claim was designed to oppose criticisms of Hindu nationalism, its validity was facilitated by Hindus' demographic majority in India. Many Hindu-American organizations' efforts toward poverty alleviation in India focus on collecting funds for poverty-alleviation programs being conducted by their partner or parent organizations in India. In doing so, Hindu-American organizations not only propagate an adjusted form of religious practice in the U.S., but also lend support to existing religious bodies (and thus existing power structures) in India. Unlike Indian-Muslim organizations, they do not frame class inequities as a failure of India's contemporary neoliberal development efforts.

\section{CONCLUSION}

Indian-American transnational organizations offer an important lens into how immigrants in the U.S. are affecting development in their home countries. Contrary to popular belief, I find that Indian religious organizations are important and sorely understudied actors in this process. Although scholars have highlighted the role of individuals and sending country states, nearly none have examined the role that transnational religious organizations play in shaping development patterns. In addition to sending financial remittances to India, I find that Indian-American Hindu and Muslim organizations are offering social remittances by trying to shape development ideologies and frameworks in India. In other words, immigrants do not only affect development outcomes, but they also shape development discourse. Examining religious organizations as a significant and unique actor in the migration and development nexus is an important contribution to existing studies that have focused on individuals and the state. 
My findings also widen our understanding of the complex processes through which immigrants construct collective religious identities and then institutionalize them through transnational organizations that interact with the Indian state to shape official development ideologies and visions for India. These processes not only expose how transnational religious organizations legitimize themselves, but also expose the wide spectrum of roles that migrants' social identities can play in shaping development patterns. Indian transnational religious organizations define their religious constituencies based on varying political, social, and economic experiences in India. Organizations' development goals, in turn, attempt to identify and empower their respective religious constituency, each of which represents a different social relationship (not just a religious practice).

Indian-Muslim organizations express their development foci as a function of the socioeconomic poverty and vulnerability that Muslims face in India. Their development efforts, therefore, focus on turning India's development rhetoric away from political stances of Hindu nationalism and social identities, away from neoliberal notions of individualism, and toward class inequities. Drawing on Muslim's vulnerable position at the bottom of India's class hierarchy, Indian Muslim-American organizations support national-level education projects to empower Muslims and develop India in the long term.

In contrast, Hindu organizations express their development foci as a function of Hindus' majority position in India's middle and upper classes and Hindu's vulnerable position as minority global religion. To empower global Hindus, Hindu-American organizations aim to boost India's position in the world system by defining India as the Hindu homeland, nurturing a shared global Hindu identity, and securing multigenerational support from successful diaspora members. To accommodate the economically diverse Hindu majority population in India, they support individual-level poverty-alleviation projects within a development framework of neoliberal capitalist ideals. These are pursued not as an attempt to overturn the structural constraints that created class inequities in the first place, but as an act of selfless service. These development efforts intersect political goals of Hindu nationalism with economic goals of self-sufficiency.

Finally, my findings remind us that U.S. immigrants' social remittances draw heavily from the power they earn from being residents in a wealthy country of the core, even though the U.S. is unrelated to their particular religious constituency. This point underlines the power that 
core countries retain on development. Indian-American Hindus and Muslims use their elite immigrant status in the U.S. when advocating their development vision to the Indian government. Indian Muslim organizations use their access to U.S. state officials to support India in their geopolitical confrontations; doing so underlines Indian Muslims' loyalties to India over Pakistan. They also use their "success stories" as high SES Muslims to promote education among Indian Muslims as a development tool. Hindu-American organizations use their access to U.S. state officials to support U.S.-India bilateral alliances and neoliberal development policies in India. They also capitalize on their high SES by ensuring migrants' multigenerational support and attention back to India; doing so enables them to boost the status of Hindus and thus India in the world system. Further research should examine how noncore country host contexts affect migrants' abilities to affect homeland development.

These findings urge us to fold transnational religious organizations into contemporary discussions on migration and development. In addition to serving as proponents of a particular religious practice or belief, they serve as important and unique actors in shaping development. In addition, they provide an important mechanism through which immigrants identify with and assist religious communities as a social group embedded in socioeconomic relations in sending regions. These relations are being used to define development visions and, therefore, demand to be recognized and analyzed. Significantly, migrants' access to core country power relations strengthens the implementation of these visions. If we continue to ignore the role that transnational religious organizations play in development, we run the risk of missing a significant share of migrants' interactions with sending countries.

\section{REFERENCES}

Agarwal, S.

2010 Daan and Other Giving Traditions in India: The Forgotten Pot of Gold. New Delhi: AccountAid India.

Anand, P.

2004 "Hindu Diaspora and Religious Philanthropy in the United States." in 6th InternaArrighi, G. tional Society for Third Sector Research. Toronto, Ontario.

1990 "The Developmentalist Illusion: A Reconceptualization of the Semiperiphery." In Semiperipheral States in the World Economy, edited by W. G. Martin. New York: Greenwood Press. 
Barth, F., ed.

1969 Ethnic Groups and Boundaries: The Social Organization of Culture Difference. London: George Allen \& Unwin.

Bermanis, S., D. Canetti-Nisim, and A. Pedahzur

2004 "Religious Fundamentalism and the Extreme Right-Wing Camp in Israel." Patterns Bhatt, C. of Prejudice 38:159-76.

1997 Liberation and Purity (Race and Representation). New York: Routledge.

Biswas, B.

2004 "Nationalism by Proxy: A Comparison of Social Movements Among Diaspora Sikhs and Hindus." Nationalism \& Ethnic Politics 10:269-95.

Brenner, R.

1985 "The Social Basis of Economic Development." In Analytical Marxism, edited by J. Roemer. Cambridge: Cambridge University Press.

Burawoy, M.

1991 Ethnography Unbound: Power and Resistance in the Modern Metropolis. Berkeley: University of California Press.

Dimaggio, P., and W. Powell

1983 "The Iron Cage Revisited: Institutional Isomorphism and Collective Rationality in Organizational Fields." American Sociological Review. Vol. 48, pp. 147-160.

Durand, J., W. Kandel, E. Parrado and D. Massey

1996 "International Migraiton and Development in Mexican Communities." Demography 33:249-64.

Dusenbery, V. A., and D. S. Tatla, eds.

2009 Sikh Diaspora Philanthropy in Punjab: Global Giving for Local Good. New York: Oxford University Press.

Ebaugh, H. R.

2010 "Transnationality and Religion in Immigrant Congregations: The Global Impact." Nordic Journal of Religion and Society 23:105-19.

- , and J. S. Chafetz

2002 Religion Across Borders: Transnational Immigrant Networks. Walnut Creek: Alta Mira.

Evans, P.

1989 "Predatory, Developmental and Other Apparatuses: A Comparative Political Economy Perspective on the Third World State." Sociological Forum 561-87. Vol 4, No. 4

Evans, P., D. Rueschemeyer, and T. Skocpol, eds.

1985 Bringing the State Back In. Cambridge: Cambridge University Press.

Evans, P., and W. H. Sewell

2013 "Neoliberalism: Policy Regimes, International Regimes, and Social Effects." In Social Resilience in the Neoliberal Era, edited by P. Hall, and M. Lamont, 35-68. Cambridge, UK: Cambridge University Press.

Fair, C. C.

2005 "Diaspora Involvement in Insurgencies: Insights from the Khalistan and Tamil Eelam Movements." Nationalism \& Ethnic Politics 11:125-56.

Falcone, J.

2006 "Seeking Recognition: Patriotism, Power and Politics in Sikh American Discourse in the Immediate Aftermath of 9/11." Diaspora: A Journal of Transnational Studies 15:89-119. 
Fenton, J. Y.

1988 Transplanting Religious Traditions: Asian Indians in America. New York: Praeger.

Frank, A. G.

1969 "Latin America: Underdevelopment or Revolution." Monthly Review Press, New York

Gereffi, G.

1994 "Rethinking Development Theory: Insights from East Asia and Latin America." In Comparative National Development: Society and Economy in the New Global Order, edited by A. D. Kinkaid, and A. Portes, 26-56. Chapel Hill: Univ. of North Carolina Press.

Gibson, C. J., and E. Lennon

1999 Historical Census Statistics on the Foreign-born Population of the United States: 1850 1990. Working Paper 29. United States Bureau of the Census Population Division. Washington D.C.

Government of India

2001 Census of India. New Delhi

Government of India and Chief Justice Rajinder Sachar

2006 Sachar Committee Report, edited by Ministry of Minority Affairs. New Delhi

Government of India, Nonresident Indians and Persons of Indian Origin Division. Ministry of External Affairs

2000 Report of the High Level Committee on the Indian Diaspora. New Delhi

Guarnizo, L. E., A. Portes, and W. Haller

2003 "Assimilation and Transnationalism: Determinants of Transnational Political Action Among Contemporary Migrants.” American Journal of Sociology 108:121-48.

de Haas, $\mathrm{H}$.

2010 "Migration and Development: A Theoretical Perspective." International Migration Review 44:227-64.

Hirschman, A.

1968 "The Political Economy of Import-Substituting Industrialization in Latin America." Quarterly Journal of Economics 82:2-32.

Huntington, S.

1968 Political Order in Changing Societies. New Haven: Yale University Press.

Iskander, $\mathrm{N}$.

2010 Creative State: Forty Years of Migration and Development Policy in Morocco and Mexico. Ithaca: Cornell University Press.

Jaffrelot, C., and I. Therwath

2007 "The Sangh Parivar and the Hindu Diaspora in the West: What Kind of Long Distance Nationalism?” International Political Sociology 1:278-95.

Jasso, G., D. S. Massey, M. R. Rosenzweig and J. P. Smith

2006 The New Immigrant Survey 2003 Round 1 (NIS-2003-1) Public Release Data. Princeton: Princeton University.

Kapur, D.

2010a Diaspora, Development, and Democracy: The Domestic Impact of International Migration from India. Princeton: Princeton University Press.

2010b "The Middle-Class in India: A Social Formation or a Political Actor?" Political Power and Social Theory 21:215-40. 
Khadria, B.

2007 "India: Skilled Migration to Developed Countries, Labor Migration to the Gulf." In Migration and Development: Perspectives from the South, edited by S. Castles, and R. D. Wise. Geneva: International Organization for Migration.

Khalidi, O., ed.

1989 Indian Muslims in North America. Watertown: South Asia Press.

Kurien, P.

2001 "Religion, Ethnicity and Politics: Hindu and Muslim Indian Immigrants in the United States." Ethnic and Racial Studies 24:263-93.

2004a "Christian by Birth and Rebirth?” In Asian American Religions, edited by T. Carnes, and F. Yang, 160-81. New York: New York University Press.

2004b "Multiculturalism, Immigrant Religion, and Diasporic Nationalism: The Development of an American Hinduism." Social Problems 51:362-85.

2005 "Being Young, Brown, and Hindu: The Identity Struggles of Second Generation Indian Americans." Journal of Contemporary Ethnography 34:434-69.

2006 "Multiculturalism and 'American' Religion: The Case of Hindu Indian Americans." Social Forces 85:723-41.

2007 "Who Speaks for Indian Americans? Religion, Ethnicity, and Political Formation." American Quarterly 59:759-83.

Leonard, K.

1997 The South Asian Americans. Westport: Greenwood Press.

2002 "South Asian Leadership of American Muslims." In Muslims in the West: From Sojourners to Citizens, edited by Y. Y. Haddad. New York: Oxford University Press. pp. 233-249.

2003 Muslims in the United States: The State of Research. New York: Russell Sage Foundations.

Levitt, P.

1998 "Local-Level Global Religion: The Case of US-Dominican Migration." Journal for the Scientific Study of Religion 37:74-89.

1999 “Social Remittances: A Local-Level, Migration-Driven Form of Cultural Diffusion.” International Migration Review 32:926-49.

2001 "Transnational Migration: Taking Stock and Future Directions." Global Networks $1: 195-216$.

2004 "Redefining the Boundaries of Belonging: The Institutional Character of Transnational Religious Life." Sociology of Religion 65:1-18.

2007 God Needs No Passport: Immigrants and the Changing American Religious Landscape. New York: New Press. 
2008 "Religion as a Path to Civic Engagement." Ethnic and Racial Studies 31:766-91.

—, and B. N. Jaworsky

2007 "Transnational Migration Studies: Past Developments and Future Trends." Annual Review of Sociology 33:129-56.

Massey, D. et al.

2008 Worlds in Motion: Understanding International Migration at the End of the Millenium. Oxford: Clarendon Press.

- J. Durand, and N. J. Malone

2002 Beyond Smoke and Mirrors: Mexican Immigration in an Era of Economic Integration. New York: Russelll Sage Foundation.

Massey, D. S., R. Alarcon, J. Durand and H. González

1987 Return to Aztlan: The Social Process of International Migration from Western Mexico. Berkeley: University of California Press.

Mathew, B., and V. Prashad

2000 "The Protean Forms of Yankee Hindutva." Ethnic and Racial Studies 23:516-34.

Meyer, J. W., and B. Rowan

1977 "Institutionalized Organizations: Formal Structure as Myth and Ceremony." American Journal of Sociology 83:340-63.

Moore, B. [1966]

1993 Social Origins of Dictatorship and Democracy: Lord and Peasant in the Making of the Modern World. Boston: Beacon Press.

Moore, K. M.

1995 Al-Mughtaribun: American Law and the Transformation of Muslim Life in the United States. Albany: SUNY University Press.

Najam, A.

2006 Portrait of a Giving Community: Philanthropy by the Pakistani-American Diaspora. Cambridge, MA: Global Equity Initiative, Asia Center, Harvard University.

Naujoks, D.

2013 Migration, Citizenship, and Development: Diasporic Membership Policies and Overseas Indians in the United States. New Delhi: Oxford University Press.

Neuman, W.

2011 Social Research Methods: Qualitative and Quantitative Approaches. Boston: Allyn \& Bacon.

Organski, A. F. K.

1965 The Stages of Political Development. New York: A.A. Knopf.

Parrenas, R.

2004 "The Care Crisis in the Phillippines." In Global Women, edited by B. Ehrinreich, and A. Hochschild, 39-54. Henry Holt Publisher, New York.

Pew Forum on Religious and Public Life

2007 "Muslim Americans: Middle Class and Mostly Mainstream." Muslim American Survey.

Portes, A., C. Escobar, and A. W. Radford

2007 "Immigrant Transnational Organizations and Development: A Comparative Study." International Migration Review 41:242-81.

- W. Haller, and L. E. Guarnizo

2002 "Transnational Entrepreneurs: The Emergence and Determinants of an Alternative Form of Immigrant Economic Adaptation." American Sociological Review 67:278-98. 
- and M. Zhou

2012 "Transnationalism and Development: Mexican and Chinese Immigrant Organizations in the United States." Population and Development Review 38:191-220.

Prashad, V.

2001 The Karma of Brown Folk. University of Minnesota Press. Minneapolis

Rajagopal, A.

1997 "Transnational Networks and Hindu Nationalism." Bulletin of Concerned Asian Scholars 29:45-58.

2000 "Hindu Nationalism in the US: Changing Configurations of Political Practice." Ethnic and Racial Studies 23:467-96.

Rodriguez, R.

2010 Migrants for Export: How the Philippine State Brokers Labor to the World. Minnesota: University of Minnesota Press.

Rodrik, D.

2005 “Feasible Globalizations." In Globalization: What's New?, edited by M. Weinstein. New York: Columbia University Press.

Rueschemeyer, D., E. Stephens, and J. Stephens

1992 Capitalist Development and Democracy. University of Chicago Press. Chicago

Russsell, S., and M. Teitelbaum

1992 International Migration and International Trade. Washington, DC: World Bank.

Taub, G.

2010 The Settlers and the Struggle Over the Meaning of Zionism. New Haven: Yale University Press.

US Census Bureau

2009 American Community Survey, United States Census Bureau, Washington D.C.

2011 American Community Survey, Washington D.C.

Valiani, S.

2012 Rethinking Unequal Exchange: The Global Integration of Nursing Labour Markets. University of Toronto Press, Toronto

Vertovec, S.

2000 The Hindu Diaspora: Comparative Patterns. Routledge. London

Wallerstein, I.

1991 Unthinking Social Science: The Limits of Nineteenth-Century Paradigms. Cambridge: Polity Press.

Walton-Roberts, M.

2012 "Contextualizing the Global Nursing Care Chain: International Migration and the Status of Nursing in Kerala, India." Global Networks 12:175-94.

Williams, R. B.

1988 Religions of Immigrants from India and Pakistan: New Threads in the American Tapestry. Cambridge: Cambridge University Press.

1998 "Asian Indian and Pakistani Religions in the US." The Annals of the American Academy of Political and Social Science 558:178-95.

World Bank

2009 Remittances. Washington, DC: World Bank.

World Bank

2011 Migration and Remittances Factbook 2011. The World Bank. Washington D.C. 
Wright, T.

1989 "Limitations on the Human Rights Approach to Problems of the Muslim Minority in India." In Indian Muslims in North America, edited by O. Khalidi. Watertown: South Asia Press.

Yang, F., and H. R. Ebaugh

2001a "Religion and Ethnicity: The Impact of Majority/Minority Status in the Home and Host Countries." Journal for the Scientific Study of Religion 40:367-78.

$\longrightarrow$, and

2001b "Transformation of New Immigrant Religions and Their Global Implications." American Sociological Review 66:269-88. 